УДК 619:534.7-7

(C) 2018

Корчан Л. М., кандидат ветеринарних наук,
Корчан М. І., кандидат ветеринарних наук

Полтавська державна аграрна академія

Приходько Ю. О., доктор ветеринарних наук, професор

Харківська державна аграрна академія

\title{
СТЕТОФОНЕНДОСКОП ДЛЯ ГРУПОВОЇ АУСКУЛЬТАЦІЇ ТВАРИН
}

\section{Рецензент - доктор ветеринарних наук, професор А. А. Замазій}

Запропонований стетофонендоскоп для групової аускультації тварин включає дві взаємозамінні звукосприймаючі головки: одну з мембраною, іншу стетоскопічну; звукорозподільний пристрій із внутрішньою сферичною акустичною камерою, яку через підвідний $і$ чотири відвідні патрубки з'єднано стандартними гнучкими звукопроводами зі звукосприймаючою головкою і пружинними наголов'ями з вушними оливами. Стетофонендоскоп для групової аускультації тварин простий у виготовленні, зручний у застосуванні за різних положень тварин, забезпечує однакове і рівномірне проведення звуків, дає можливість одночасного спільного вислуховування звуків кількома фахівцями під час проведення консультативної діагностики, може бути використаний для підвищення якості навчального прочесу під час освоєння методики аускультаиії студентами.

Ключові слова: стетофонендоскоп, аускультація, прослуховування, тварини, діагностика, звуки, прилад.

Постановка проблеми. Незважаючи на технологічний прогрес і велику оснащеність технікою під час комплексного дослідження як людини, так і тварини, аускультація залишається незамінним діагностичним методом прослуховування шумів внутрішніх органів: легень, серця, шлунка, кишечнику; для визначення артеріального тиску за способом Короткова, розпізнавання артеріовенозних і внутрішньочерепних аневризм, в акушерській практиці та інше.

Частіше проводять опосередковану аускультацію за допомогою стетоскопа, фонендоскопа або їх комбінації - стетофонендоскопа. Існують як механічні, так і деякі електронні варіанти цих пристроїв для аускультації [1, 2, 4, 5-9].

У наш час як у гуманній, так і у ветеринарній медицині для аускультації більш доступні та переважно використовують механічні стетофонендоскопи, які мають дві звукосприймаючі голівки: одну 3 мембраною (фонендоскоп), другу без неї (стетоскоп), гнучкі звукопроводи і пружинне наголов'я 3 наконечниками для вух лікаря (вушні оливи).
Аналіз основних досліджень і публікацій, у яких започатковано розв'язання проблеми. У літературних джерелах висвітлено чимало модифікацій стетофонендоскопу [2, 7-9], які недостатньо ефективні, мають окремі недоліки і в практиці до цього часу не знайшли необхідного застосування.

Проте, як свідчить практика, за допомогою стетоскопічної голівки краще вислуховуються низькі (низькочастотні) звуки, а за допомогою голівки 3 мембраною - більш високі (високочастотні) звуки, які посилюються пристроєм. Такі стетоскопи та фонендоскопи мають просту конструкцію, невисоку ціну, доступні навіть рядовому громадянину. Проте такі механічні пристрої для аускультації не дають можливості одночасно вислуховувати тварину кількома спеціалістами, що буває дуже важливо під час проведення консультативної діагностики. Вони також недостатньо ефективні для навчання аускультації, не дадуть можливості ефективно використовувати працю викладача - в кожний момент він зайнятий із одним студентом, окрім того не гарантують ідентичність сприйняття звукової картини.

Електронні стетоскопи чи фонендоскопи, які поки що застосовуються лише в деяких клініках гуманної медицини, суттєво розширяють функціональні можливості аускультаціі, візуалізують сигнали, ідеальні для навчання аускультації, дають змогу кільком користувачам одночасно слухати одні й ті ж звуки. Однак електронні пристрої для аускультації мають і низку недоліків: ціна їх достатньо висока, вони не дають можливості вислуховувати звукові явища в органах у чистому вигляді, оскільки їх еластичні трубки піддаються коливанням повітряного середовища (відсутність у них віброзахисту). В електронному фонендоскопі видозміни звукових явищ можуть бути внаслідок шумів власних датчиків і підсилювачів.

Для групової аускультації запропонований механічний фонендоскоп, який використовують на лабораторно-практичних заняттях студентів для дослідження органів тварин [6]. 


\section{ВЕТЕРИНАРНА МЕДИЦИНА}

У конструкцію цього фонендоскопа введена нова деталь - розгалужувач, що дає можливість одночасно вислуховувати досліджуваний орган викладачу та трьом студентам чи одночасно прослуховувати орган кількома спеціалістами.

Розгалужувач являє собою три латунних патрубки, що приєднанні з боку до основного звукопроводу за допомогою пайки. Довжина патрубків 25 мм із внутрішнім діаметром 6 мм. Передній край основного звукопроводу зігнутий коліном у протилежному напрямку припаяних латунних патрубків і до нього приєднана голівка 3 мембраною. Усі інші елементи - гнучкі звукопроводи, пружинне наголов'я 3 вушними оливами стандартні. Проте недоліком такої конструкції фонендоскопа є те, що акустична енергія, яка надходить від голівки фонендоскопа розподіляється нерівномірно по чотирьом каналам - в один прямий звукопровід і в три бокові припаєні патрубки. Інтенсивність звуку в кожному із чотирьох каналів буде не однакова. У бокових каналах такого фонендоскопа інтенсивність звуку, звичайно, зменшується. Та і сам процес з'єднання звукопровідних патрубків із основним звукопроводом за допомогою припаювання може змінити діаметри їх отворів.

Недоліком такої конструкції фонендоскопа є й те, що таке вищеописане 3'єднання голівки 3 основним звукопроводом i припаяними до нього трьома боковими звукопровідними патрубками створюють об'ємне нагромадження деталей, через яке голівку незручно підвести, наприклад, під плече або лопатку тварини для проведення аускультації серця, легень тощо, особливо, під час вимушеного лежачого положення тварини. У такому пристрої для аускультації тварин відсутня також і стетоскопічна голівка.

Мета роботи - створення простого у виготовленні стетофонендоскопа для групової аускультації тварин шляхом усунення недоліків близької конструкції, а саме: за рахунок розширення його конструктивних та функціональних можливостей забезпечити однакове i рівномірне проведення звуків, краще вислуховування не лише більш високих, але й низьких звуків; покращання акустичних властивостей, зручності в застосуванні за різних положень, особливо, великих тварин.

Опис приладу та принциип його використання. Запропонований нами стетофонендоскоп для групової аускультації тварин (рис. А) включає дві з'ємні взаємозамінні звукосприймаючі голівки: одну з мембраною діаметром 63 мм (1), іншу - стетоскопічну 3 таким же діаметром їі воронки (2); звукорозподільний пристрій (3), стандартний гнучкий звукопровід довжиною 200 мм, (4); стандартні гнучкі звукопроводи довжиною 540 мм; (5) і пружинні наголов'я (6) з вушними оливами (7).

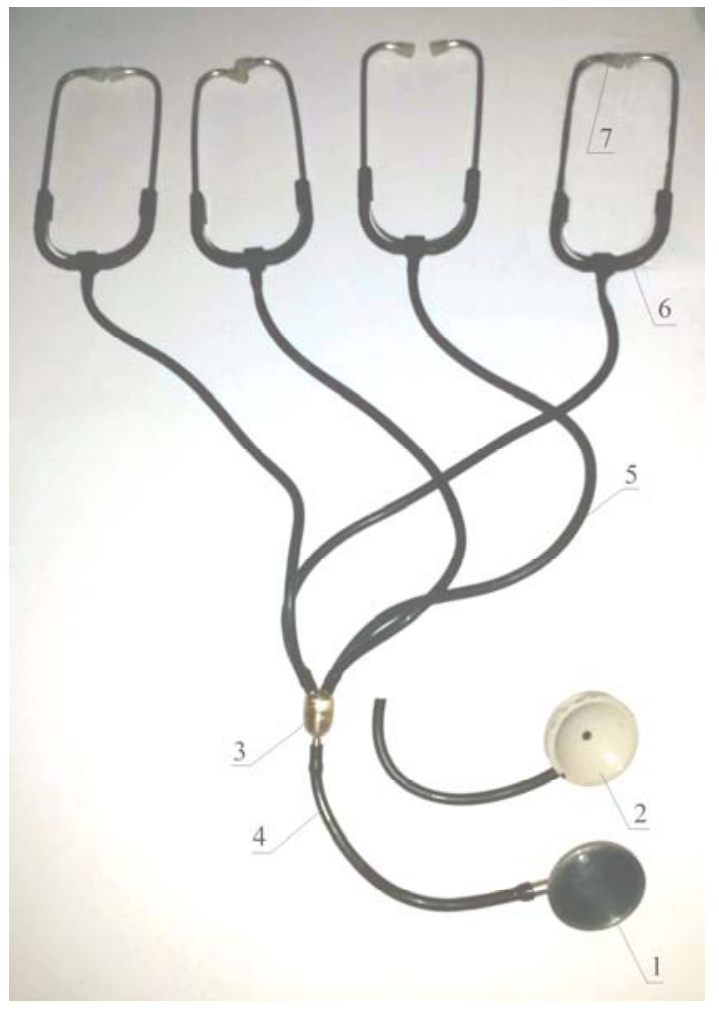

Рис. А. Стетофонендоскоп для групової аускультації тварин 

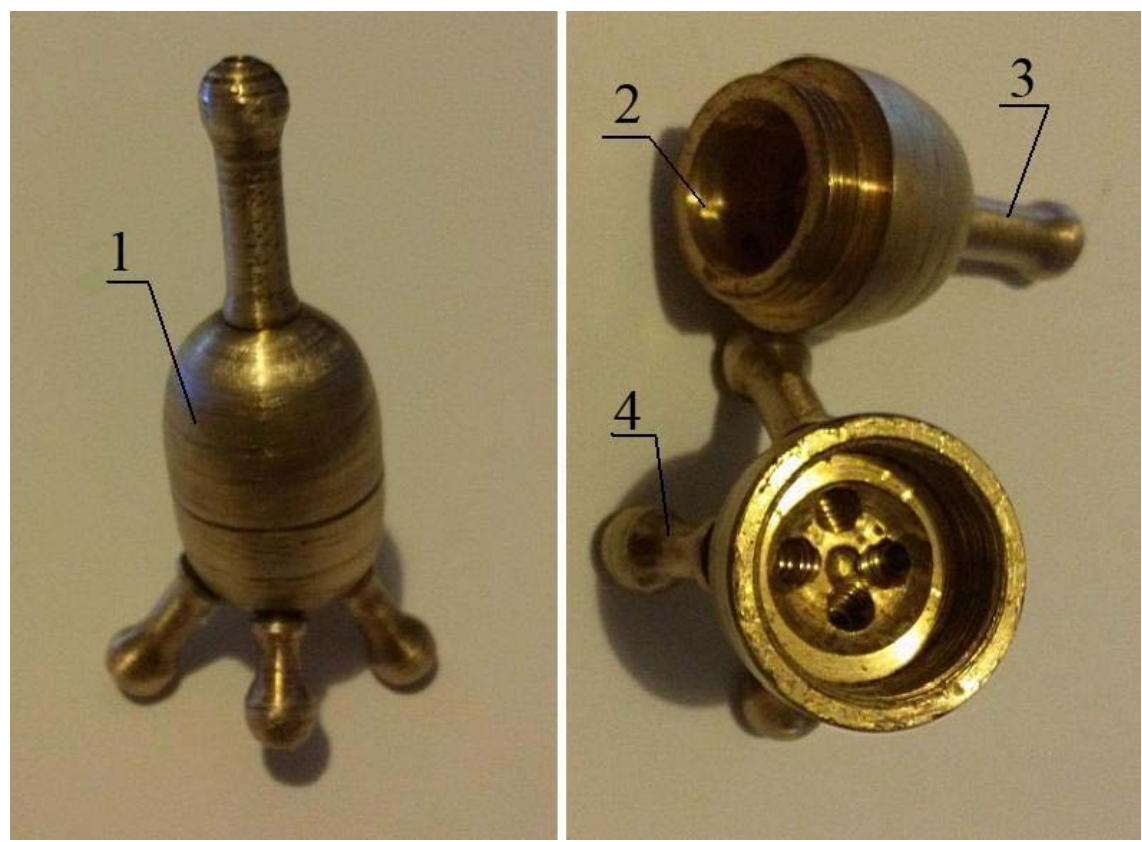

Рис. Б. Звукорозподільний пристрій

Велика площа голівок стетофонендоскопа сприяє достатній глибині прослуховування внутрішніх органів великих тварин і їх легко підсовувати під лопатку, плече та інші ділянки тіла, особливо, за вимушеного лежачого положення тіла.

Звукорозподільний пристрій (рисунок Б) складається із корпуса (1), всередині якого виточена та відшліфована сферична акустична камера діаметром 25 мм (2); підвідного (3) та чотирьох відвідних патрубків довжиною 20 мм (4), які під кутом $45^{\circ}$ на однаковій відстані один від одного мають різьбове з'єднання з акустичною камерою. Внутрішній діаметр патрубків для застереження видозмін звуку відповідає внутрішньому діаметру стандартних гнучких звукопроводів і становить 6 мм. Така конструкція звукорозподільного пристрою сприяє рівномірному розподілу акустичної енергії, що надходить від голівки та направляється в чотири його вихідні канали.

Вільний кінець підвідного патрубка звукорозподільного пристрою з'єднаний гнучким звукопроводом довжиною 200 мм 3 голівкою, а вільні кінці відвідних патрубків з'єднані через стандартні гнучкі звукопроводи довжиною 540 мм 3 пружинними наголов'ями та вушними оливами.

Звукорозподільний пристрій з метою запобігання його власних резонансних звукових явищ виготовляється із латуні.

Результати дослідження. Ми запропонували стетофонендоскоп для групової аускультації тварин, що використовується наступним чином.
Кілька аускультуючих осіб (до чотирьох, наприклад, викладач і три студенти) надівають пружинні наголов'я і вставляють вушні оливи у вуха, а звукоприймаючу голівку (з мембраною або стетоскопічну) підносять і притискають до необхідної ділянки тіла тварини (серця, легеневого поля та ін.). При цьому звуки від досліджуваної тварини через звукосприймаючу голівку по гнучкому звукопроводу надходять у звукорозподільний пристрій, звідки знову по гнучким звукопроводам направляються до вушних олив $\mathrm{i}$ сприймаються аускультуючими особами.

Розроблений стетофонендоскоп для групової аускультації тварин було апробовано на значному поголів'ї великої та дрібної рогатої худоби, коней. На даний стетофонендоскоп для групової аускультації тварин отримано деклараційний патент [3].

Тож, ми вважаємо за доцільне налагодити промислове виробництво стетофонендоскопа для групової аускультації тварин і впровадити його у практику ветеринарної медицини.

Висновок. Запропонований стетофонендоскоп для групової аускультації тварин має просту конструкцію, зручний у використанні, особливо, за вимушено лежачого положення великих тварин, забезпечує однакове і рівномірне проведення звуків (однакової частоти); дає можливість одночасного спільного вислуховування тварин кількома фахівцями під час проведення консультативної діагностики; може бути використаний для підвищення якості навчального процесу під час освоєння методики аускультації студентами. 


\section{БІБЛІОГРАФІЯ}

1. Внутрішні незаразні хвороби тварин : підручник. - 2-ге вид., доп. / [Судаков М. О., Цвіліховський М. І., Береза В. І. та ін.] ; за ред. М. О. Судакова. - К. : Мета, 2002. - 352 с.

2. Вовк И. В. Экспериментальное исследование помех, возникающих при регистрации дыхательных шумов электронными стетофонендоскопами / И. В. Вовк, А. А. Макаренкова // Акустичний вісник. - 2007. - Т. 10, №4. - С. 28-34.

3. Деклараційний патент на корисну модель № 9163/3У/15 від 04.06.2015 Україна, МПК А61В7/00 (2015.01). Стетофонендоскоп для групової аускультації тварин / Корчан Л. М., Корчан М. І., Приходько П. Ю. // № u 2015 00802 ; заявл. 02.02.2015.

4. Каталог ветеринарных и зоотехнических инструментов, аппаратов, приборов и оборудования стран-членов СЭВ / под общ. ред. А. С. Макеева, Л. М. Соколовой. - М. : Колос, 1972. - C. 10-11.
5. Клінічна діагностика внутрішніх хвороб тварин / [Левченко В. І., Влізло В. В., Кондрахін І. П. та ін.] ; за ред. В. І. Левченка. - Біла Церква, 2004. - C. 18-21.

6. Лукъянчиков О. Н. Фонендоскоп для групповой аускультации / О. Н. Лукъянчиков, А. Т. Лабзина, М. П. Артамонов // Ветеринария. - 1986. - №12. - C. 71.

7. Обзор нескольких моделей кардиологических стетоскопов: личный опыт. Блог Шпака Я. В. [Электронный ресурс]. - Режим доступа : http://medicalmanuscript.blogspot.com/2012/07/blo g-post_26.html.

8. Олийнык В. Н. Частотные искажения, вносимыми контактными датчиками при одно- и двухканальной регистрации шумов дыхания / В. Н. Олийнык // Гидромеханика. - 1997. - Вып. 71. - C. 89-97.

9. Стетоскопы MDF и электронный стетоскоп Jades [Электронный pecypc]. - Режим доступа : http://heaco.ua/stetoskops. 